\title{
Electrophilic Activation of Amides for the Preparation of Poly- substituted Pyrimidines
}

\author{
Tobias Stopka \\ Pauline Adler $^{\diamond}$ \\ Gerhard Hagn \\ Haoqi Zhang \\ Veronica Tona \\ Nuno Maulide* [ \\ University of Vienna, Institute of Organic Chemistry, Währinger Strasse 38, \\ 1090 Vienna, Austria \\ nuno.maulide@univie.ac.at \\ $\diamond$ These authors contributed equally. \\ Published as part of the 50 Years SYNTHESIS - Golden Anniversary Issue
}

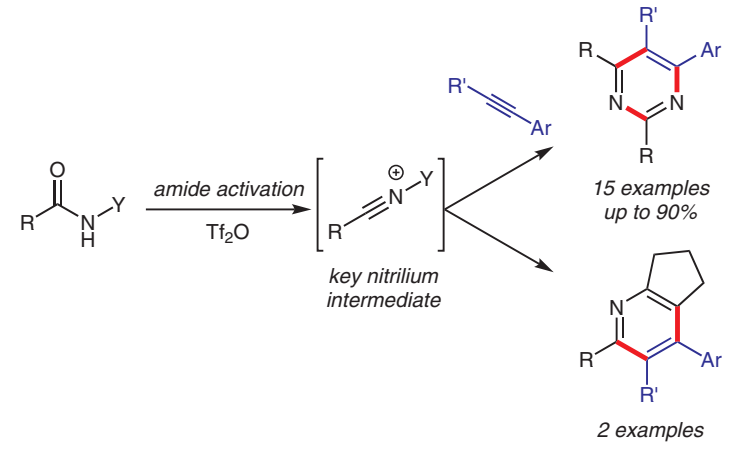

Another approach which has gained traction in recent Received: 10.11.2018

Accepted: 16.11 .2018

Published online: 07.12 .2018

DOI: 10.1055/s-0037-1610411; Art ID: ss-2018-z0755-fa

License terms: cc)

Abstract In this article we describe the straightforward synthesis of polysubstituted pyrimidines by electrophilic activation of secondary amides in the presence of alkynes. An unusual mechanistic detour leading to pyridine derivatives as products is also presented and briefly discussed.

Key words pyrimidines, amide activation, hydride shift, pyridines

Heteroaromatics occupy a prominent role in organic chemistry. ${ }^{1}$ Among them, the pyrimidine core is present in several natural products, pharmaceuticals and functional materials. ${ }^{2}$ For these reasons, numerous methods have been developed throughout the years to prepare these motifs (Scheme 1). The most popular method for the synthesis of pyrimidines remains the condensation of amidines with carbonyls (Scheme 1, a). ${ }^{2 \mathrm{a}, 3}$ a)

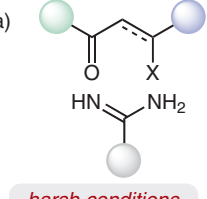

c)

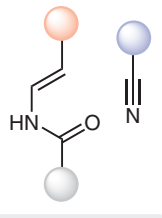

limited to enamides b)

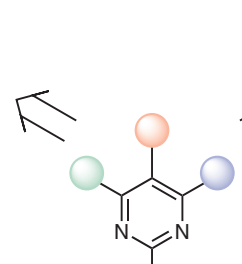

L

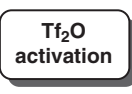<smiles>CCCC</smiles>

transition-metal catalysis

d) Our approach

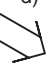

readily available amides

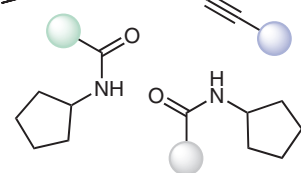

Scheme 1 Classical formation of pyrimidines and our approach years is the metal-catalyzed $[2+2+2]$ cycloaddition between an alkyne and two nitriles (Scheme 1, b). ${ }^{4}$ Recently, our group reported a metal-free version of this reaction using ynamides and relying on triflic acid for the activation of the $\mathrm{C} \equiv \mathrm{C}$ bond. ${ }^{5}$ Movassaghi and co-workers developed a straightforward synthesis of pyrimidines by electrophilic activation of a secondary enamide with triflic anhydride (Scheme 1, c). ${ }^{6}$ In that elegant report, the requirement for an electron-rich alkene in the form of the enamide partner somewhat limits the scope of the reaction. We herein propose an approach consisting of a three-component reaction that merges one alkyne and two secondary amides under an electrophilic activation regime (Scheme 1, d).

We started our investigation of this transformation by employing $N$-cyclopentylbenzamide (1a), 2-iodopyridine as a base and prop-1-yn-1-ylbenzene as alkyne partner (Table 1).

Already on our first trial (Table 1, entry 1 ) using 3 equivalents of amide, base and triflic anhydride, the expected pyrimidine 2a was obtained in 60\% NMR yield. Other halogenated bases were screened, such as 2-fluoropyridine and 2chloropyridine (Table 1, entries 2 and 3), resulting in an increase to $77 \%$ and $81 \%$ yield, respectively. During these experiments, we became aware of the non-negligible effect of the quenching method employed. In the event, we found that stirring for 1 hour at room temperature with a saturated aqueous solution of sodium bicarbonate increased the yield (Table 1, entry 4 ), up to $88 \%$ with 2 -iodopyridine. Further variation of the base (Table 1 , entry 5 ) or the loading of activated amide (Table 1 , entry 6 ) led only to lower yields. Finally, we decided to modify the $\mathrm{N}$-amide substituent and investigated $\mathrm{N}$-isopropyl- and $\mathrm{N}$-propylbenzamide. Both were less effective than $\mathbf{1 a}$ (yielding 57\% and 0\%, respectively; cf. Table 1, entries 7 and 8). 


\section{Biographical Sketches}
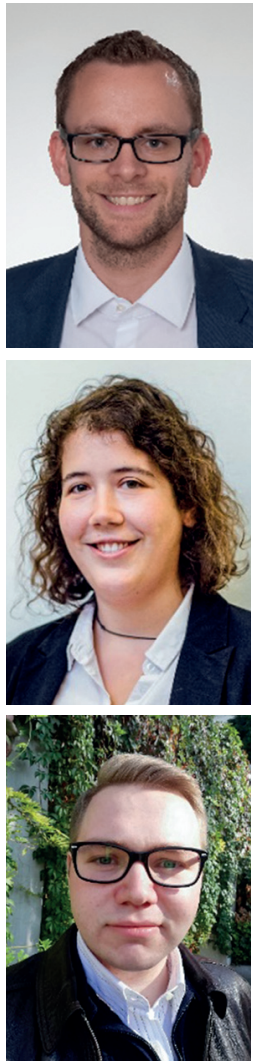

Gerhard Hagn was born in 1991 in Schärding, Austria. He obtained his Bachelor's degree in chemistry working on molecular dynamics simulations of ionic
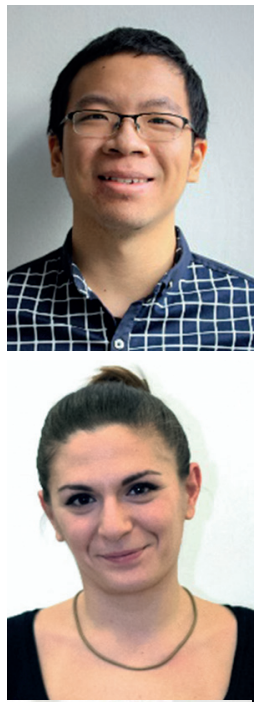

Veronica Tona was born in 1990 in Loreto, Italy. She obtained her Bachelor's and Master's degrees from the University of Camerino (Italy) under the supervision of

Prof. Nuno Maulide was born in 1979 in Lisbon, Portugal and since 2013 has been a Full Professor and Chair of Organic Synthesis at the University of Vienna (Austria). Prior to that, he was a Max Planck Group Leader at the Max-PlanckInstitut für Kohlenforschung (Mülheim, Germany) from 2009, following PhD studies at the Université catholique de Louvain, Belgium (Prof. I. E. Markó) and a group of Prof. Dr. Meike Niggemann at the RWTH Aachen (Germany) working on reactions based on vinyl cations as reactive intermediates. In 2017, he successfully defended his PhD and graduated with honors. For his dissertation he was awarded the Borchers Badge. Until 2018 he was a postdoctoral researcher in the group of Prof. Nuno Maulide in Vienna (Austria) where he worked on sulfur ylide based transformations and amide activation. Currently, he is working as a business consultant.

the Université Paris-Sud in 2013 with honors. Thanks to a 'Allocation Spécifique pour Normalien' doctoral research grant from the French Ministry of Higher Education and Research, she started a PhD in the group of Dr. Nicolas Rabasso on the study of the synthesis and reactivity of

liquids at the University of Vienna (Austria), Department of Computational Biological Chemistry. To complete his M.Sc. degree, he joined the group of Prof.

synthetic studies towards the total synthesis of virol A, in the group of Prof. Maulide. His interests lie in synthetic chemistry and he will continue his Mas-

Prof. Marcantoni. Since 2015, she has been a PhD student in the group of Prof. Maulide in Vienna (Austria). Her research interests include electrophilic amide acti-

postdoctoral stay at Stanford University, USA (Prof. B. M. Trost). Prof. Maulide is a regular speaker at international symposia and conferences, having delivered over 20 invited/plenary lectures per year since 2012. His research interests revolve around the exploration of rearrangements and high-energy intermediates in organic chemistry, and have been acknowledged by several awards (including unsaturated aminophosphonates. She defended her PhD in 2016. Since 2017, she has been working as a postdoctoral researcher in the group of Prof. Maulide in Vienna (Austria). Her work is focused on the chemoselective activation of amides.

Christopher Gerner at the University of Vienna, Department of Analytical Chemistry.

ter's studies in the field of organic and biological chemistry at the University of Vienna.

vation and metal-free amination reactions.

the Bayer Early Excellence Award 2012, the Heinz Maier-Leibnitz Prize 2013, the EurJOC Young Researcher Award 2015, the Elisabeth Lutz Prize of the Austrian Academy of Sciences 2016, the Springer Heterocyclic Chemistry Award 2018, and three ERC Grants - StG 2011, CoG 2016 and PoC 2018). He was elected corresponding member of the Austrian Academy of Sciences in 2018. 
Table 1 Optimization of the Reaction ${ }^{\text {a }}$

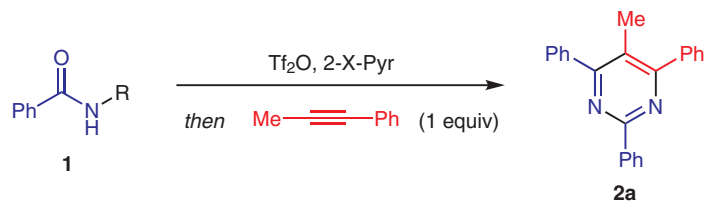

\begin{tabular}{|c|c|c|c|c|c|c|}
\hline Entry & $\mathrm{R}$ & Amide & 2-X-Pyr & $\mathrm{Tf}_{2} \mathrm{O}$ & Comment & NMR yield ${ }^{\mathrm{b}}$ \\
\hline 1 & & 3 equiv & 2-I-Pyr (3 equiv) & 3 equiv & - & $60 \%$ \\
\hline 2 & & 3 equiv & 2-F-Pyr (3 equiv) & 3 equiv & - & $77 \%$ \\
\hline 3 & & 3 equiv & 2-Cl-Pyr (3 equiv) & 3 equiv & - & $81 \%$ \\
\hline 4 & & 3 equiv & 2-I-Pyr (3 equiv) & 3 equiv & quench $1 \mathrm{~h}, \mathrm{NaHCO}_{3}$ & $88 \%(83 \% c)$ \\
\hline 5 & & 3 equiv & 2-Cl-Pyr (3 equiv) & 3 equiv & quench $1 \mathrm{~h}, \mathrm{NaHCO}_{3}$ & $79 \%$ \\
\hline 6 & & 2.5 equiv & 2-I-Pyr (2.5 equiv) & 2.5 equiv & quench $1 \mathrm{~h}, \mathrm{NaHCO}_{3}$ & $69 \%$ \\
\hline 7 & & 3 equiv & 2-I-Pyr (3 equiv) & 3 equiv & quench $1 \mathrm{~h}, \mathrm{NaHCO}_{3}$ & $57 \%$ \\
\hline 8 & & 3 equiv & 2-I-Pyr (3 equiv) & 3 equiv & quench $1 \mathrm{~h}, \mathrm{NaHCO}_{3}$ & $0 \%$ \\
\hline
\end{tabular}

${ }^{a}$ Reaction conditions: amide, 2-halopyridine, 1,2-dichloroethane $(3 \mathrm{~mL}), 0{ }^{\circ} \mathrm{C}$; addition of $\mathrm{Tf}_{2} \mathrm{O}$, after $15 \mathrm{~min}$, addition of alkyne $(0.2 \mathrm{mmol}, 1 \mathrm{equiv}) ; 90{ }^{\circ} \mathrm{C}, 18 \mathrm{~h}$. ${ }^{b}$ NMR yield calculated using 1,3,5-trimethoxybenzene as internal standard.

c Isolated yield.

Triflic anhydride is well-known to chemoselectively activate tertiary and secondary amides., ${ }^{7,8}$ We propose the following mechanism to explain the observed reactivity (Scheme 2). The secondary amide $\mathbf{1}$ is activated as nitrilium ion RI-1, reversibly stabilized by 2 -iodopyridine (cf. RI2). ${ }^{7 \mathrm{~b}, 9}$ This pivotal nitrilium species can evolve either to the nitrile 3 by loss of cyclopentyl carbocation (presumably favoured by high temperatures), or undergo addition of the alkyne reactant to generate the vinyl cation RI-3. The latter is stabilized by the vicinal aryl group, accounting for the regioselectivity observed in this process. Interception of RI-3 by nitrile $\mathbf{3}$ (cf. RI-4) sets the stage for cyclization to the pyrimidinium ion RI-5. A second elimination of cyclopentyl carbocation finally accounts for the formation of the pyrimidine product. ${ }^{10}$

With optimized conditions in hand and the aforementioned mechanistic understanding, we investigated the scope of this reaction (Scheme 3). We started by varying the alkyne partner, keeping $N$-cyclopentylbenzamide (1a) as the amide reactant. The pyrimidine $\mathbf{2 a}$ prepared during optimization could be isolated in a very good $83 \%$ yield. Alkyne substitution with an ethyl $(\mathbf{2 b})$ or phenyl $(\mathbf{2 c})$ residue did not affect the reaction. Terminal alkynes are also tolerated (2d). Chlorination of the alkyne's aromatic moiety yielded the pyrimidines $\mathbf{2 e}$ and $\mathbf{2 f}$ efficiently, and the fluorinated pyrimidine $\mathbf{2} \mathbf{g}$ was accessible by this method in moderate yield.
For the investigation of the amide scope, prop-1-yn-1ylbenzene was retained as the alkyne partner (Scheme 4). The arylamide can be substituted ortho or meta ( $\mathbf{2 h}$ and $\mathbf{2 i})$, and the presence of halogens on the aromatic ring is also well-tolerated (2j), including fluorine (2k, $90 \%$ yield). A benzamide is not a prerequisite for successful reaction and it was possible to prepare pyrimidine $\mathbf{2} \mathbf{m}$ starting from a tert-

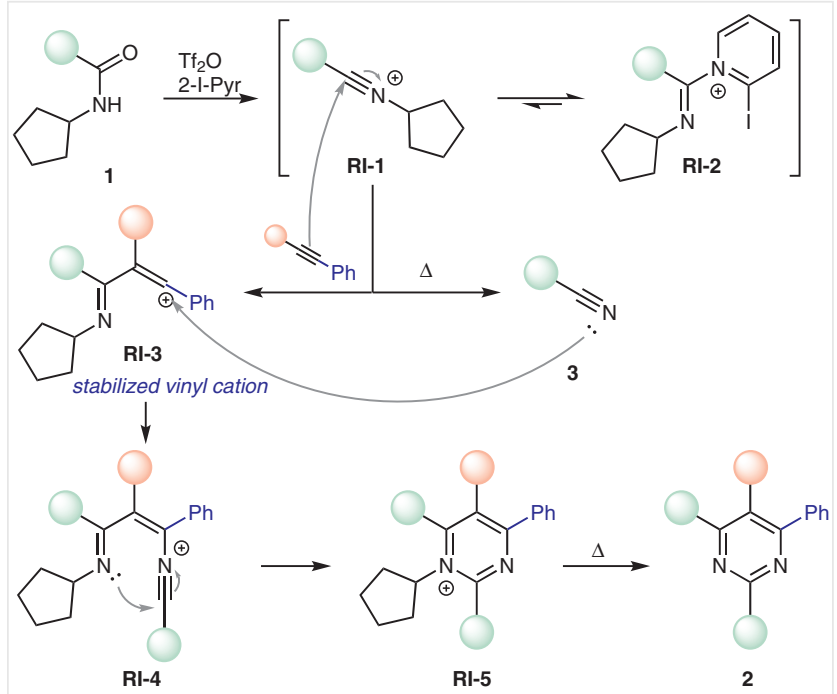

Scheme 2 Mechanistic proposal for the pyrimidine synthesis reported herein 
<smiles>O=C(NC1CCCC1)c1ccccc1</smiles><smiles></smiles>

$1 a$

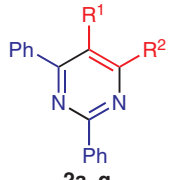
2a-g<smiles>CCc1c(-c2ccccc2)nc(-c2ccccc2)nc1-c1ccccc1</smiles><smiles>O=[W]c1ccccc1-c1nc(-c2ccccc2)nc(-c2ccccc2)c1-c1ccccc1</smiles><smiles>O=[N+]([O-])c1c(-c2ccccc2)nc(-c2ccccc2)nc1-c1ccc(Cl)cc1</smiles><smiles>Cc1cc(F)ccc1-c1cc(-c2ccccc2)nc(-c2ccccc2)n1</smiles>

Scheme 3 Scope of the alkyne. Reagents and conditions: amide (0.6 mmol, 3 equiv), 2-iodopyridine (3 equiv), 1,2-dichloroethane ( $3 \mathrm{~mL})$, $0{ }^{\circ} \mathrm{C}$; addition of $\mathrm{Tf}_{2} \mathrm{O}$ (3 equiv), after $15 \mathrm{~min}$, addition of alkyne ( 1 equiv); $90^{\circ} \mathrm{C}, 18 \mathrm{~h}$. Quench: saturated $\mathrm{NaHCO}_{3}$ solution, stirring, $1 \mathrm{~h}$, r.t.

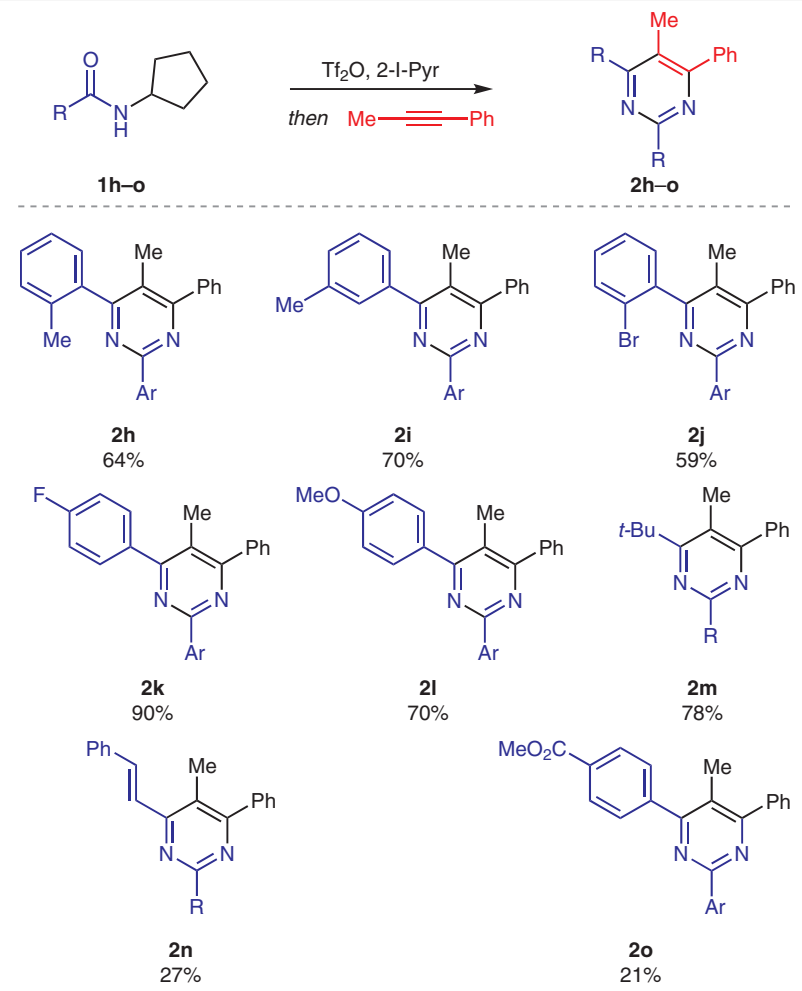

Scheme 4 Scope of the amide. Reagents and conditions: amide (0.6 mmol, 3 equiv), 2-iodopyridine (3 equiv), 1,2-dichloroethane ( $3 \mathrm{~mL})$, $0{ }^{\circ} \mathrm{C}$; addition of $\mathrm{Tf}_{2} \mathrm{O}$ ( 3 equiv), after $15 \mathrm{~min}$, addition of alkyne (1 equiv); $90^{\circ} \mathrm{C}, 18$ h. Quench: saturated $\mathrm{NaHCO}_{3}$ solution, stirring, 1 h, r.t. butyl amide. Alkenyl amides and benzamides carrying electron-withdrawing substituents led to lower yields, presumably due to less efficient electrophilic activation (2n, 2o).

In the course of this study, we noticed that no pyrimidine was formed when particularly electron-rich alkynes were employed. Instead, as depicted in Scheme 5 , a pyridine derivative was isolated. Indeed, from 1-ethynyl-4-methoxybenzene, pyridine 3a was obtained in a moderate $45 \%$ yield. A propargylsilane similarly led to a (desilylated) pyridine (3b). Such cycloannulated pyridines can be found in agrochemicals and pharmaceuticals, ${ }^{11}$ and are commonly prepared by condensation reactions, in particular the Friedländer annulation. ${ }^{12}$

This unexpected reactivity is rationalized by invoking a 1,5-hydride shift on the intermediate RI-3 to form the carbocation RI-6/azoniaallene RI-6'. Deprotonation thereof yields the imine RI-7 poised for a $6 \pi$-electrocyclization step towards the dihydropyridine $4 .{ }^{13}$ We presume that $\mathbf{4}$ undergoes disproportionation ${ }^{14}$ to tetrahydropyridine (also detected by HRMS) and pyridine $\mathbf{3}$, the latter being the only product that can be isolated from the reaction mixture. It is

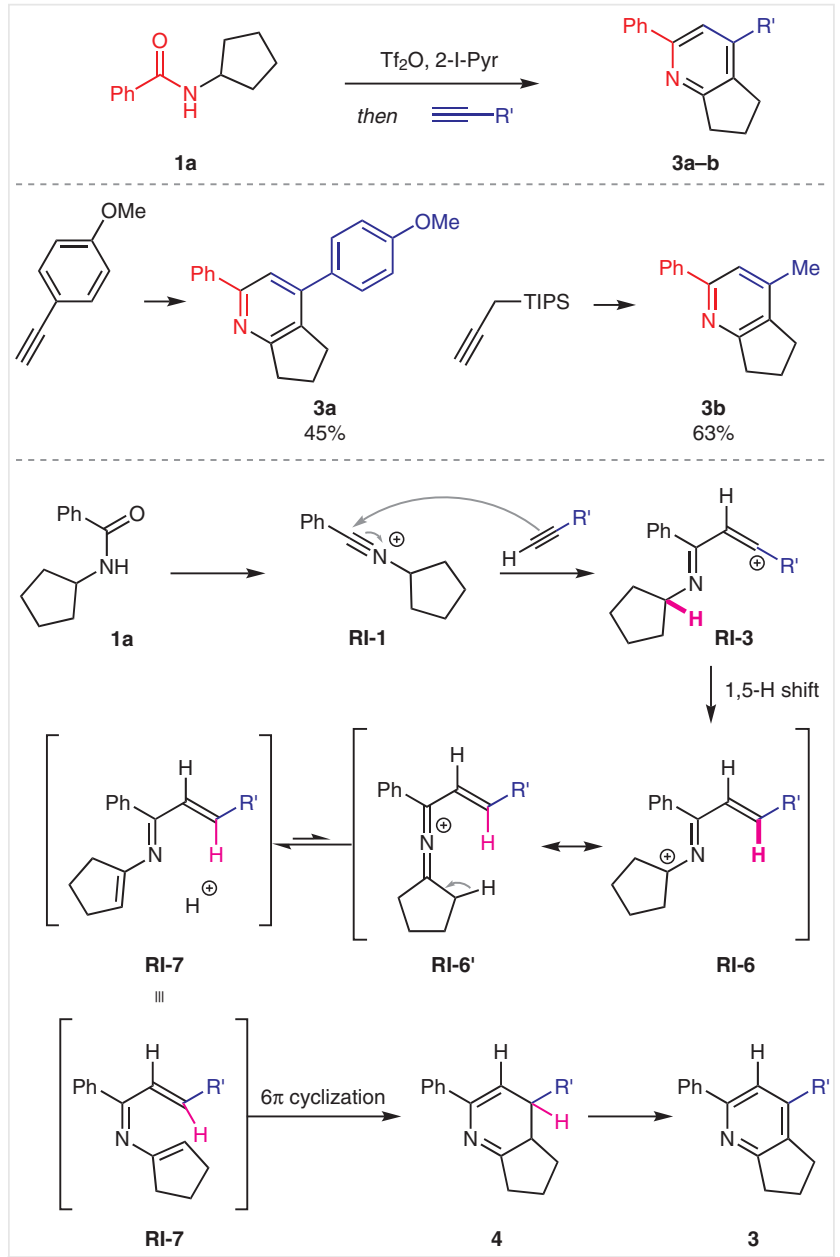

Scheme 5 Unexpected formation of a pyridine core 
tempting to presume that the aforementioned (cf. Scheme 2) nitrile capture of RI-3 dominates for 'less-stabilized' versions of this intermediate, whereas the intramolecular hydride-transfer pathway is favoured by increased stabilization (and thus increased lifetime in solution) of RI-3.

In conclusion, we have developed a new and efficient access to pyrimidines by formal cycloaddition of 2 equivalents of an appropriately substituted amide and an alkyne. We believe this work is complementary to other methods for the preparation of pyrimidines and benefits from the ready availability of both starting materials. Furthermore, an unusual pathway towards pyridines was uncovered, presumably relying on an internal hydride transfer.

All glassware was flame-dried before use and all reactions were performed under an atmosphere of argon. All solvents were distilled from appropriate drying agents prior to use. Triflic anhydride $\left(\mathrm{Tf}_{2} \mathrm{O}\right)$ was distilled over $\mathrm{P}_{4} \mathrm{O}_{10}$ prior to use. All other reagents were used as received from commercial suppliers unless otherwise stated. Reaction progress was monitored by TLC performed on aluminum plates coated with silica gel $\mathrm{F}_{254}$ with $0.2 \mathrm{~mm}$ thickness. Chromatograms were visualized by fluorescence quenching with UV light at $254 \mathrm{~nm}$ or by staining using potassium permanganate. Flash column chromatography was performed using silica gel 60 (230-400 mesh, Merck and Co.). Neat IR spectra were recorded using a Perkin-Elmer Spectrum 100 FT-IR spectrometer. Wavenumbers are reported in $\mathrm{cm}^{-1}$. Mass spectra were obtained using a Finnigan MAT $8200(70 \mathrm{eV})$ or an Agilent $5973(70 \mathrm{eV})$ spectrometer, using electrospray ionization (ESI). All ${ }^{1} \mathrm{H}$ NMR, ${ }^{13} \mathrm{C}$ NMR and ${ }^{19} \mathrm{~F}$ NMR spectra were recorded using a Bruker AV-400, AV-600 or AV-700 spectrometer at $300 \mathrm{~K}$. Chemical shifts are given in parts per million ( $\mathrm{ppm}, \delta$ ), referenced to the solvent peak of $\mathrm{CDCl}_{3}$, defined at $\delta=7.26 \mathrm{ppm}\left({ }^{1} \mathrm{H}\right.$ NMR $)$ and $\delta=77.16 \mathrm{ppm}$ $\left({ }^{13} \mathrm{C}\right.$ NMR). Coupling constants $(\mathrm{J})$ are quoted in $\mathrm{Hz} .{ }^{1} \mathrm{H}$ NMR splitting patterns are designated as singlet ( $\mathrm{s}$ ), doublet $(\mathrm{d})$, triplet $(\mathrm{t})$, quartet $(q)$, pentet (p). Splitting patterns that could not be interpreted or easily visualized are designated as multiplet ( $\mathrm{m}$ ) or broad (br). Selected ${ }^{13} \mathrm{C}$ NMR spectra were recorded using the attached proton test (APT) to facilitate the confirmation and assignment of the structure.

\section{Synthesis of Amides}

\section{General Procedure A}

To a solution of the amine (1.00 equiv) and $\mathrm{Et}_{3} \mathrm{~N}$ (2.00 equiv) in DCM $(0.1 \mathrm{M})$ at $0{ }^{\circ} \mathrm{C}$, the corresponding acyl chloride (1.20 equiv) was added dropwise and the resulting reaction mixture was allowed to warm to room temperature while stirring overnight (14 h). After this time, saturated aqueous $\mathrm{NaHCO}_{3}$ solution was added and the biphasic system was separated. The aqueous phase was extracted with DCM $(1 \times)$ and the organic phases were combined and dried over anhydrous $\mathrm{Na}_{2} \mathrm{SO}_{4}$. The dried solution was filtered and concentrated under reduced pressure. The resulting crude material was purified by flash column chromatography on silica gel (heptane/EtOAc) to afford the desired compound.

\section{Procedure B}

To a solution of the amine (1.00 equiv), $\mathrm{Et}_{3} \mathrm{~N}$ (1.00 equiv), hydroxybenzotriazole (HOBt, 1.00 equiv) and 1-ethyl-3-(3-dimethylaminopropyl)carbodiimide hydrochloride ( $\mathrm{EDCl} \cdot \mathrm{HCl}, 1.00$ equiv) in $\mathrm{DCM}$
$(0.1 \mathrm{M})$, the corresponding carboxylic acid was added and the resulting solution was stirred at room temperature overnight (14 h). After this time, the organic solution was extracted sequentially with $1 \mathrm{M}$ aqueous $\mathrm{HCl}$, saturated aqueous $\mathrm{NaHCO}_{3}$ solution and saturated aqueous $\mathrm{NaCl}$ solution. The washed solution was dried over anhydrous $\mathrm{Na}_{2} \mathrm{SO}_{4}$, filtered and concentrated under reduced pressure. The resulting crude material was purified by flash column chromatography on silica gel (heptane/EtOAc) to afford the desired compound.

\section{Procedure C}

To a solution of the carboxylic acid (1.00 equiv) and DMF ( 1 drop) in DCM $(0.1 \mathrm{M})$ was added dropwise thionyl chloride (2.00 equiv) at room temperature. The resulting solution was stirred at room temperature overnight $(14 \mathrm{~h})$. After this time, the thionyl chloride and solvent were removed under reduced pressure to afford the acyl chloride. To a solution of the amine (1.00 equiv) and $\mathrm{Et}_{3} \mathrm{~N}$ ( 1.50 equiv) in $\operatorname{DCM}(0.1 \mathrm{M})$ at $0{ }^{\circ} \mathrm{C}$, the corresponding acyl chloride (1.00 equiv) was added dropwise and the resulting reaction mixture was allowed to warm to room temperature while stirring overnight $(14 \mathrm{~h})$. After this time, saturated aqueous $\mathrm{NaHCO}_{3}$ solution was added and the biphasic system was separated. The aqueous phase was extracted with DCM ( 1 $x$ ) and the organic phases were combined and dried over anhydrous $\mathrm{Na}_{2} \mathrm{SO}_{4}$. The dried solution was filtered and concentrated under reduced pressure. The resulting crude material was purified by flash column chromatography on silica gel (heptane/EtOAc) to afford the desired compound.

\section{$N$-Cyclopentylbenzamide (1a)}

General Procedure A; 97\% yield. All analytical data were in good accordance with reported data. ${ }^{15}$

\section{$N$-Isopropylbenzamide}

General Procedure A; quant. All analytical data were in good accordance with reported data. ${ }^{16}$

\section{$N$-Propylbenzamide}

General Procedure A; quant. All analytical data were in good accordance with reported data. ${ }^{17}$

\section{$\mathbf{N}$-Cyclopentyl-2-methylbenzamide (1h)}

General Procedure A; quant. All analytical data were in good accordance with reported data. ${ }^{18}$

\section{N-Cyclopentyl-3-methylbenzamide (1i)}

General Procedure A; 95\% yield. All analytical data were in good accordance with reported data. ${ }^{19}$

\section{2-Bromo- $N$-cyclopentylbenzamide (1j)}

General Procedure A; light-yellow solid, quant.; mp 96-98 ${ }^{\circ} \mathrm{C}$.

IR (neat): 3244, 3066, 2952, 2866, 1628, 1593, 1541, 1468, 1430, $1360,1320,1277,1259,1187,1044,1027,754,729,694 \mathrm{~cm}^{-1}$.

${ }^{1} \mathrm{H}$ NMR $\left(600 \mathrm{MHz}, \mathrm{CDCl}_{3}\right): \delta=7.56(\mathrm{dd}, J=8.0,1.0 \mathrm{~Hz}, 1 \mathrm{H}), 7.52(\mathrm{dd}$, $J=7.6,1.7 \mathrm{~Hz}, 1 \mathrm{H}), 7.34(\mathrm{td}, J=7.5,1.1 \mathrm{~Hz}, 1 \mathrm{H}), 7.26-7.22(\mathrm{~m}, 1 \mathrm{H})$, 5.93 (br s, $1 \mathrm{H}$ ), 4.46-4.37 (m, $1 \mathrm{H}), 2.10-2.03(\mathrm{~m}, 2 \mathrm{H}), 1.75-1.63(\mathrm{~m}$, $4 \mathrm{H}), 1.58-1.52(\mathrm{~m}, 2 \mathrm{H})$.

${ }^{13} \mathrm{C}$ NMR (151 MHz, $\left.\mathrm{CDCl}_{3}\right): \delta=167.2,138.2,133.4,131.2,129.8$, $127.7,119.4,52.0,33.1,23.9$.

HRMS (ESI+): $m / z$ [M $+\mathrm{H}]^{+}$calcd for $\mathrm{C}_{12} \mathrm{H}_{15} \mathrm{BrNO}$ : 268.0332; found: 268.0336 . 


\section{$\mathrm{N}$-Cyclopentyl-4-fluorobenzamide (1k)}

[CAS Reg. No. 300829-28-1]

General Procedure A; light-yellow solid, 96\% yield; mp 133-135 ${ }^{\circ} \mathrm{C}$. IR (neat): 3277, 3077, 2957, 2870, 1628, 1602, 1543, 1501, 1364, $1324,1289,1160,1099,1015,850,768 \mathrm{~cm}^{-1}$.

${ }^{1} \mathrm{H}$ NMR $\left(700 \mathrm{MHz}, \mathrm{CDCl}_{3}\right): \delta=7.78-7.71(\mathrm{~m}, 2 \mathrm{H}), 7.12-7.04(\mathrm{~m}, 2 \mathrm{H})$, $6.02(\mathrm{~s}, 1 \mathrm{H}), 4.42-4.33(\mathrm{~m}, 1 \mathrm{H}), 2.13-2.05(\mathrm{~m}, 2 \mathrm{H}), 1.75-1.62(\mathrm{~m}, 4$ $\mathrm{H}), 1.53-1.44(\mathrm{~m}, 2 \mathrm{H})$.

${ }^{13} \mathrm{C}$ NMR $\left(176 \mathrm{MHz}, \mathrm{CDCl}_{3}\right): \delta=165.8(\mathrm{~d}, J=140.4 \mathrm{~Hz}), 164.0,131.2(\mathrm{~d}$, $J=2.6 \mathrm{~Hz}), 129.3(\mathrm{~d}, J=8.9 \mathrm{~Hz}), 115.6(\mathrm{~d}, J=21.9 \mathrm{~Hz}), 51.9,33.4,23.9$. HRMS (ESI+): $m / z[\mathrm{M}+\mathrm{Na}]^{+}$calcd for $\mathrm{C}_{12} \mathrm{H}_{14} \mathrm{FNNaO}$ : 230.0952; found: 230.0956.

\section{$\mathrm{N}$-Cyclopentyl-4-methoxybenzamide (11)}

General Procedure A; 90\% yield. All analytical data were in good accordance with reported data. ${ }^{20}$

\section{$\mathrm{N}$-Cyclopentylpivalamide (1m)}

General Procedure A; 92\% yield. All analytical data were in good accordance with reported data. ${ }^{21}$

\section{N-Cyclopentylcinnamamide (1n)}

Procedure B; 84\% yield. All analytical data were in good accordance with reported data. ${ }^{22}$

\section{Methyl 4-(Cyclopentylcarbamoyl)benzoate (10)}

[CAS Reg. No. 1325090-17-2]

Procedure C; light-yellow solid, $85 \%$ yield; $172-174{ }^{\circ} \mathrm{C}$.

IR (neat): 3297, 2957, 2870, 1719, 1632, 1541, 1435, 1280, 1108, 869, $749 \mathrm{~cm}^{-1}$.

${ }^{1} \mathrm{H}$ NMR $\left(600 \mathrm{MHz}, \mathrm{CDCl}_{3}\right): \delta=8.09-8.06(\mathrm{~m}, 2 \mathrm{H}), 7.82-7.77(\mathrm{~m}, 2 \mathrm{H})$, $6.09(\mathrm{~d}, J=5.9 \mathrm{~Hz}, 1 \mathrm{H}), 4.44-4.38(\mathrm{~m}, 1 \mathrm{H}), 3.94(\mathrm{~s}, 3 \mathrm{H}), 2.15-2.07(\mathrm{~m}$, $2 \mathrm{H}), 1.78-1.63(\mathrm{~m}, 4 \mathrm{H}), 1.54-1.46(\mathrm{~m}, 2 \mathrm{H})$.

${ }^{13} \mathrm{C}$ NMR $\left(151 \mathrm{MHz}, \mathrm{CDCl}_{3}\right): \delta=166.5,166.4,139.0,132.7,130.0$, 127.1, 52.5, 52.0, 33.4, 24.0.

HRMS (ESI+): $m / z[\mathrm{M}+\mathrm{Na}]^{+}$calcd for $\mathrm{C}_{14} \mathrm{H}_{17} \mathrm{NNaO}_{3}: 270.1101$; found: 270.1104 .

\section{Synthesis of Pyrimidines 2a-o; General Procedure}

All reactions were run on a $0.2 \mathrm{mmol}$ scale.

To a solution of amide ( $0.6 \mathrm{mmol}, 3$ equiv) and 2-iodopyridine (2-I$\mathrm{Pyr}, 3$ equiv) in 1,2-dichloroethane ( $3 \mathrm{~mL}$ ), $\mathrm{Tf}_{2} \mathrm{O}$ ( 3 equiv) was added at $0{ }^{\circ} \mathrm{C}$. The reaction mixture was stirred for $15 \mathrm{~min}$ at $0{ }^{\circ} \mathrm{C}$. The alkyne ( 1 equiv) was then added and the reaction mixture was stirred at $90{ }^{\circ} \mathrm{C}$ for $18 \mathrm{~h}$. After cooling to room temperature, the reaction was quenched with saturated aqueous $\mathrm{NaHCO}_{3}$ solution $(3 \mathrm{~mL})$ and the mixture was stirred for $1 \mathrm{~h}$. Then, the aqueous layer was extracted with DCM. The combined organic layers were dried over $\mathrm{MgSO}_{4}$ and the solvent was removed under reduced pressure. The crude residue was purified by flash column chromatography on silica gel (eluent: heptane).

\section{5-Methyl-2,4,6-triphenylpyrimidine (2a)}

Yield: $83 \%$

${ }^{1} \mathrm{H}$ NMR (400 MHz, $\left.\mathrm{CDCl}_{3}\right): \delta=8.62-8.57(\mathrm{~m}, 2 \mathrm{H}), 7.79-7.73(\mathrm{~m}, 4 \mathrm{H})$, 7.58-7.45 (m, $9 \mathrm{H}), 2.40(\mathrm{~s}, 3 \mathrm{H})$
${ }^{13} \mathrm{C}$ NMR (101 MHz, $\mathrm{CDCl}_{3}$ ): $\delta=167.1,161.6,139.4,138.1,130.4$, $129.5,129.2,128.5,128.42,128.35,123.3,17.9$.

HRMS (ESI+): $m / z[\mathrm{M}+\mathrm{H}]^{+}$calcd for $\mathrm{C}_{23} \mathrm{H}_{19} \mathrm{~N}_{2}$ : 323.1543; found: 323.1539 .

All analytical data were in good accordance with reported data. ${ }^{23}$

\section{5-Ethyl-2,4,6-triphenylpyrimidine (2b)}

Yield: $72 \%$

${ }^{1} \mathrm{H}$ NMR $\left(400 \mathrm{MHz}, \mathrm{CDCl}_{3}\right): \delta=8.59-8.40(\mathrm{~m}, 2 \mathrm{H}), 7.67-7.62(\mathrm{~m}, 4 \mathrm{H})$, 7.55-7.48 (m, $6 \mathrm{H}), 7.48-7.41(\mathrm{~m}, 3 \mathrm{H}), 2.84(\mathrm{q}, J=7.5 \mathrm{~Hz}, 2 \mathrm{H}), 0.80$ (t, $J=7.5 \mathrm{~Hz}, 3 \mathrm{H})$.

${ }^{13} \mathrm{C}$ NMR $\left(101 \mathrm{MHz}, \mathrm{CDCl}_{3}\right): \delta=167.3,161.4,139.8,138.0,130.4$, $129.9,128.90,128.88,128.5,128.4,21.8,14.6$.

HRMS (ESI+): $m / z[M+H]^{+}$calcd for $\mathrm{C}_{24} \mathrm{H}_{21} \mathrm{~N}_{2}$ : 337.1699; found: 337.1694 .

All analytical data were in good accordance with reported data. ${ }^{24}$

\section{2,4,5,6-Tetraphenylpyrimidine (2c)}

Yield: $71 \%$

${ }^{1} \mathrm{H} \mathrm{NMR}\left(400 \mathrm{MHz}, \mathrm{CDCl}_{3}\right): \delta=8.68-8.62(\mathrm{~m}, 2 \mathrm{H}), 7.54-7.47(\mathrm{~m}, 3 \mathrm{H})$, 7.45-7.38 (m, $4 \mathrm{H}), 7.32-7.27$ ( $\mathrm{m}, 3 \mathrm{H}), 7.26-7.21$ (m, $3 \mathrm{H}), 7.20-7.13$ (m, $3 \mathrm{H}), 7.03-6.97$ (m, $2 \mathrm{H})$.

${ }^{13} \mathrm{C}$ NMR $\left(101 \mathrm{MHz}, \mathrm{CDCl}_{3}\right): \delta=165.5,163.0,139.0,137.9,136.8$, 131.3, 130.7, 130.1, 129.2, 128.8, 128.6, 128.6, 128.4, 127.9, 127.4 .

HRMS (ESI+): $m / z$ [M $+\mathrm{Na}]^{+}$calcd for $\mathrm{C}_{28} \mathrm{H}_{20} \mathrm{~N}_{2} \mathrm{Na}$ : 407.1519; found: 407.1509.

All analytical data were in good accordance with reported data. ${ }^{25}$

\section{2,4,6-Triphenylpyrimidine (2d)}

Yield: $41 \%$.

${ }^{1} \mathrm{H}$ NMR $\left(400 \mathrm{MHz}, \mathrm{CDCl}_{3}\right): \delta=8.79-8.68(\mathrm{~m}, 2 \mathrm{H}), 8.38-8.24(\mathrm{~m}, 4 \mathrm{H})$, $8.03(\mathrm{~s}, 1 \mathrm{H}), 7.64-7.47(\mathrm{~m}, 9 \mathrm{H})$.

${ }^{13} \mathrm{C}$ NMR $\left(101 \mathrm{MHz}, \mathrm{CDCl}_{3}\right): \delta=165.0,164.7,138.3,137.8,130.9$, $130.8,129.1,128.64,128.60,127.5,110.5$.

HRMS (ESI+): $m / z[\mathrm{M}+\mathrm{H}]^{+}$calcd for $\mathrm{C}_{22} \mathrm{H}_{17} \mathrm{~N}_{2}$ : 309.1386; found: 309.1386 .

All analytical data were in good accordance with reported data. ${ }^{23}$

\section{4-(2-Chlorophenyl)-5-methyl-2,6-diphenylpyrimidine (2e)}

Yellow solid, $58 \%$ yield; $\mathrm{mp} 156-159{ }^{\circ} \mathrm{C}$.

IR (neat): 3059, 2959, 2926, 2862, 1596, 1534, 1393, 1194, 1095 $1069,1040,1028,984 \mathrm{~cm}^{-1}$.

${ }^{1} \mathrm{H} \mathrm{NMR}\left(400 \mathrm{MHz}, \mathrm{CDCl}_{3}\right): \delta=8.54(\mathrm{dd}, J=6.7,2.9 \mathrm{~Hz}, 2 \mathrm{H}), 7.81-7.74$ ( $\mathrm{m}, 2 \mathrm{H}), 7.57-7.38(\mathrm{~m}, 10 \mathrm{H}), 2.22(\mathrm{~s}, 3 \mathrm{H})$.

${ }^{13} \mathrm{C}$ NMR $\left(101 \mathrm{MHz}, \mathrm{CDCl}_{3}\right): \delta=166.4,166.0,161.8,139.1,138.6$, 137.9, 132.6, 130.4, 130.1, 129.9, 129.5, 129.3, 128.5, 128.4, 127.2, 124.8, 16.3.

HRMS (ESI+): $m / z[\mathrm{M}+\mathrm{Na}]^{+}$calcd for $\mathrm{C}_{23} \mathrm{H}_{17} \mathrm{ClN}_{2} \mathrm{Na}$ : 379.0972; found: 379.0970 .

4-(4-Chlorophenyl)-5-methyl-2,6-diphenylpyrimidine (2f) Yellow solid, 59\% yield; mp $148-149{ }^{\circ} \mathrm{C}$.

IR (neat): 3061, 2962, 2926, 1597, 1572, 1533, 1489, 1445, 1391, $1090,1005 \mathrm{~cm}^{-1}$. 
${ }^{1} \mathrm{H}$ NMR $\left(400 \mathrm{MHz}, \mathrm{CDCl}_{3}\right): \delta=8.64-8.51(\mathrm{~m}, 2 \mathrm{H}), 7.81-7.67(\mathrm{~m}, 4 \mathrm{H})$, 7.58-7.42 (m, $8 \mathrm{H}), 2.39$ (s, $3 \mathrm{H})$.

${ }^{13} \mathrm{C}$ NMR $\left(101 \mathrm{MHz}, \mathrm{CDCl}_{3}\right): \delta=167.3,165.8,161.7,139.2,137.9$, $137.8,135.5,131.0,130.5,129.5,129.3,128.7,128.5,128.4,128.3$, 123.2, 17.8 .

HRMS (ESI+): $m / z$ [M $+\mathrm{Na}]^{+}$calcd for $\mathrm{C}_{23} \mathrm{H}_{17} \mathrm{ClN}_{2} \mathrm{Na}$ : 379.0972; found: 379.0964 .

\section{4-(4-Fluoro-2-methylphenyl)-2,6-diphenylpyrimidine (2g)}

Light-yellow solid, $57 \%$ yield; $\mathrm{mp} 119-120^{\circ} \mathrm{C}$.

IR (neat): 3063, 3038, 2930, 1590, 1569, 1529, 1497, 1361, 1248, $1179,1117,1027 \mathrm{~cm}^{-1}$.

${ }^{1} \mathrm{H}$ NMR $\left(400 \mathrm{MHz}, \mathrm{CDCl}_{3}\right): \delta=8.74-8.67(\mathrm{~m}, 2 \mathrm{H}), 8.31-8.26(\mathrm{~m}, 2 \mathrm{H})$, $8.14(\mathrm{dd}, J=7.3,1.5 \mathrm{~Hz}, 1 \mathrm{H}), 8.11-8.07(\mathrm{~m}, 1 \mathrm{H}), 7.94(\mathrm{~s}, 1 \mathrm{H}), 7.61-$ $7.49(\mathrm{~m}, 6 \mathrm{H}), 7.18(\mathrm{t}, J=8.8 \mathrm{~Hz}, 1 \mathrm{H}), 2.43(\mathrm{~s}, 3 \mathrm{H})$.

${ }^{13} \mathrm{C}$ NMR $\left(151 \mathrm{MHz}, \mathrm{CDCl}_{3}\right): \delta=164.6,164.4(\mathrm{~d}, J=127.2 \mathrm{~Hz}), 164.2$, $162.5,138.2,137.6,133.4(\mathrm{~d}, J=3.4 \mathrm{~Hz}), 130.9,130.8,130.7(\mathrm{~d}, J=5.8$ $\mathrm{Hz}), 129.0,128.6,127.4,126.7(\mathrm{~d}, J=8.7 \mathrm{~Hz}), 125.6(\mathrm{~d}, J=17.7 \mathrm{~Hz})$, $115.7(\mathrm{~d}, J=22.8 \mathrm{~Hz}), 110.0,14.9(\mathrm{~d}, J=3.4 \mathrm{~Hz})$

${ }^{19} \mathrm{~F} \operatorname{NMR}\left(659 \mathrm{MHz}, \mathrm{CDCl}_{3}\right): \delta=-114.0$.

HRMS (ESI+): $m / z[\mathrm{M}+\mathrm{H}]^{+}$calcd for $\mathrm{C}_{23} \mathrm{H}_{18} \mathrm{FN}_{2}$ : 341.1449; found: 341.1446.

\section{5-Methyl-4-phenyl-2,6-di-o-tolylpyrimidine (2h)}

Yellow solid, $64 \%$ yield; mp $149-152^{\circ} \mathrm{C}$.

IR (neat): 3059, 3022, 2956, 2921, 2855, 1602, 1529, 1487, 1391, $1379,1002,875,772,762,732,704 \mathrm{~cm}^{-1}$.

${ }^{1} \mathrm{H}$ NMR $\left(400 \mathrm{MHz}, \mathrm{CDCl}_{3}\right): \delta=8.30(\mathrm{dd}, J=4.5,1.7 \mathrm{~Hz}, 1 \mathrm{H}), 7.81(\mathrm{dd}$, $J=7.6,2.0 \mathrm{~Hz}, 1 \mathrm{H}), 7.67-7.60$ (m, $3 \mathrm{H}), 7.46-7.37$ (m, $3 \mathrm{H}), 7.28-7.15$ (m, $5 \mathrm{H}), 2.53(\mathrm{~s}, 3 \mathrm{H}), 2.18(\mathrm{~s}, 3 \mathrm{H}), 2.10(\mathrm{~s}, 3 \mathrm{H})$.

${ }^{13} \mathrm{C}$ NMR $\left(101 \mathrm{MHz}, \mathrm{CDCl}_{3}\right): \delta=168.5,166.1,164.6,150.9,139.1$, 139.0, 138.6, 137.7, 137.3, 135.3, 135.2, 131.2, 130.7, 130.6, 129.4, 129.2, 129.1, 128.7, 128.4, 126.0, 125.9, 123.6, 123.1, 21.5, 19.8, 16.4 . HRMS (ESI+): $m / z[\mathrm{M}+\mathrm{Na}]^{+}$calcd for $\mathrm{C}_{25} \mathrm{H}_{22} \mathrm{~N}_{2} \mathrm{Na}$ : 373.1675; found: 373.1673 .

\section{5-Methyl-4-phenyl-2,6-di-m-tolylpyrimidine (2i)}

Yellow solid, $70 \%$ yield; $\mathrm{mp} 115-118{ }^{\circ} \mathrm{C}$

IR (neat): 3062, 3029, 2957, 2924, 2857, 2734, 1529, 1389, 1376, $1010,787,765,695 \mathrm{~cm}^{-1}$.

${ }^{1} \mathrm{H}$ NMR $\left(400 \mathrm{MHz}, \mathrm{CDCl}_{3}\right): \delta=8.30-8.25(\mathrm{~m}, 2 \mathrm{H}), 7.68-7.61(\mathrm{~m}, 2 \mathrm{H})$, 7.47-7.34 (m, 5 H), 7.33-7.12 (m, 4 H), 2.37 (s, 3 H), $2.34(\mathrm{~s}, 3 \mathrm{H}), 2.27$ (s, $3 \mathrm{H})$.

${ }^{13} \mathrm{C}$ NMR $\left(101 \mathrm{MHz}, \mathrm{CDCl}_{3}\right): \delta=167.3,166.9,161.8,139.5,139.4$, $138.1,138.0,131.1,130.0,129.9,129.5,129.2,128.8,128.4,128.3$, $126.5,125.6,123.2,21.6,17.8,17.8$.

HRMS (ESI+): $m / z[\mathrm{M}+\mathrm{Na}]^{+}$calcd for $\mathrm{C}_{25} \mathrm{H}_{22} \mathrm{~N}_{2} \mathrm{Na}$ : 373.1675; found: 373.1671 .

\section{2,4-Bis(2-bromophenyl)-5-methyl-6-phenylpyrimidine (2j)}

Yellow solid, 59\% yield; ; mp $141-143{ }^{\circ} \mathrm{C}$.

IR (neat): 3055, 2926, 2857, 2226, 1557, 1534, 1391, 906, 755, 726, $699 \mathrm{~cm}^{-1}$.

${ }^{1} \mathrm{H} \operatorname{NMR}\left(400 \mathrm{MHz}, \mathrm{CDCl}_{3}\right): \delta=7.78-7.22(\mathrm{~m}, 13 \mathrm{H}), 2.23(\mathrm{~s}, 3 \mathrm{H})$.
${ }^{13} \mathrm{C}$ NMR $\left(101 \mathrm{MHz}, \mathrm{CDCl}_{3}\right): \delta=167.1,166.3,163.3,139.9,139.8$, 138.3, 133.6, 132.9, 131.7, 130.2, 130.2, 130.0, 129.4, 129.3, 128.4, $127.8,127.4,124.9,122.0,121.9,16.3$.

HRMS (ESI+): $m / z$ [M+H] calcd for $\mathrm{C}_{23} \mathrm{H}_{17} \mathrm{Br}_{2} \mathrm{~N}_{2}: 478.9753$; found: 478.9752 .

\section{2,4-Bis(4-fluorophenyl)-5-methyl-6-phenylpyrimidine (2k)}

Yellow solid, $90 \%$ yield; $\mathrm{mp} 148-150^{\circ} \mathrm{C}$.

IR (neat): 3057, 3025, 2928, 2861, 1713, 1601, 1532, 1507, 1392, $1379,1222,1149,1006,842,808,772,734,697 \mathrm{~cm}^{-1}$.

${ }^{1} \mathrm{H}$ NMR $\left(600 \mathrm{MHz}, \mathrm{CDCl}_{3}\right): \delta=8.59-8.54(\mathrm{~m}, 2 \mathrm{H}), 7.78-7.71(\mathrm{~m}, 4 \mathrm{H})$, 7.56-7.49 (m, $3 \mathrm{H}), 7.22(\mathrm{t}, J=8.7 \mathrm{~Hz}, 2 \mathrm{H}), 7.14(\mathrm{t}, J=8.7 \mathrm{~Hz}, 2 \mathrm{H}), 2.39$ (s, $3 \mathrm{H})$.

${ }^{13} \mathrm{C}$ NMR (151 MHz, $\left.\mathrm{CDCl}_{3}\right): \delta=167.3,166.0,164.9(\mathrm{~d}, J=176.7 \mathrm{~Hz})$, $163.2(\mathrm{~d}, J=176.4 \mathrm{~Hz}), 160.7,139.1,135.3(\mathrm{~d}, J=3.3 \mathrm{~Hz}), 134.1(\mathrm{~d}, J=$ $2.8 \mathrm{~Hz}), 131.5(\mathrm{~d}, J=8.4 \mathrm{~Hz}), 130.4(\mathrm{~d}, J=8.5 \mathrm{~Hz}), 129.4,129.4,128.5$, $123.1,115.5(\mathrm{~d}, J=11.1 \mathrm{~Hz}), 115.4(\mathrm{~d}, J=11.0 \mathrm{~Hz}), 17.9$.

${ }^{19} \mathrm{~F}$ NMR $\left(565 \mathrm{MHz}, \mathrm{CDCl}_{3}\right): \delta=-111.1(\mathrm{tt}, J=8.4,5.6 \mathrm{~Hz}),-111.8(\mathrm{tt}$, $J=8.6,5.5 \mathrm{~Hz})$.

HRMS (ESI+): $m / z[\mathrm{M}+\mathrm{Na}]^{+}$calcd for $\mathrm{C}_{23} \mathrm{H}_{16} \mathrm{~F}_{2} \mathrm{~N}_{2} \mathrm{Na}$ : 381.1174; found: 381.1168 .

\section{2,4-Bis(4-methoxyphenyl)-5-methyl-6-phenylpyrimidine (21)}

Yellow solid, $70 \%$ yield; $\mathrm{mp} 182-185^{\circ} \mathrm{C}$.

IR (neat): 3068, 3054, 3004, 2993, 2959, 2834, 1607, 1583, 1529, $1507,1392,1377,1246,1163,1030,834,806,776,712 \mathrm{~cm}^{-1}$.

${ }^{1} \mathrm{H} \mathrm{NMR}\left(600 \mathrm{MHz}, \mathrm{CDCl}_{3}\right): \delta=8.56(\mathrm{~d}, J=8.9 \mathrm{~Hz}, 2 \mathrm{H}), 7.78-7.73(\mathrm{~m}, 4$ H), 7.55-7.51 (m, $2 \mathrm{H}), 7.50-7.47(\mathrm{~m}, 1 \mathrm{H}), 7.06(\mathrm{~d}, J=8.7 \mathrm{~Hz}, 2 \mathrm{H})$, $7.00(\mathrm{~d}, J=8.9 \mathrm{~Hz}, 2 \mathrm{H}), 3.89$ (s, $3 \mathrm{H}), 3.87(\mathrm{~s}, 3 \mathrm{H}), 2.40$ (s, $3 \mathrm{H}$ ).

${ }^{13} \mathrm{C}$ NMR $\left(151 \mathrm{MHz}, \mathrm{CDCl}_{3}\right): \delta=166.9,166.3,161.5,161.2,160.5$, 139.6, 131.8, 131.1, 130.9, 129.8, 129.5, 129.1, 128.3, 122.1, 113.7, $55.5,55.4,18.0$.

HRMS (ESI+): $m / z[\mathrm{M}+\mathrm{Na}]^{+}$calcd for $\mathrm{C}_{25} \mathrm{H}_{22} \mathrm{~N}_{2} \mathrm{NaO}_{2}$ : 405.1570; found: 405.1573 .

\section{2,4-Di-tert-butyl-5-methyl-6-phenylpyrimidine (2m)}

Yellow solid, $78 \%$ yield; $\mathrm{mp} 43-46{ }^{\circ} \mathrm{C}$.

IR (neat): 2956, 2925, 2868, 1535, 1495, 1479, 1458, 1400, 1376, $1276,1261,1243,1004,915,765,750,700 \mathrm{~cm}^{-1}$.

${ }^{1} \mathrm{H} \mathrm{NMR}\left(400 \mathrm{MHz}, \mathrm{CDCl}_{3}\right): \delta=7.57-7.50(\mathrm{~m}, 2 \mathrm{H}), 7.49-7.38(\mathrm{~m}, 3 \mathrm{H})$, $2.39(\mathrm{~s}, 3 \mathrm{H}), 1.50(\mathrm{~s}, 9 \mathrm{H}), 1.43(\mathrm{~s}, 9 \mathrm{H})$.

${ }^{13} \mathrm{C}$ NMR $\left(100 \mathrm{MHz}, \mathrm{CDCl}_{3}\right): \delta=173.6,172.3,166.6,140.6,129.5$, $128.4,128.2,121.7,40.0,39.3,29.9,29.8,17.8$.

HRMS (ESI+): $m / z[\mathrm{M}+\mathrm{H}]^{+}$calcd for $\mathrm{C}_{19} \mathrm{H}_{27} \mathrm{~N}_{2}: 283.2169$; found: 283.2172 .

\section{5-Methyl-4-phenyl-2,6-di((E)-styryl)pyrimidine (2n)}

Yellow solid, 27\% yield; $\mathrm{mp} 193-196{ }^{\circ} \mathrm{C}$.

IR (neat): 3081, 3059, 3024, 2923, 1629, 1575, 1521, 1494, 1447, $1394,1375,1296,1191,1174,1114,1041,1025,966,764,742 \mathrm{~cm}^{-1}$.

${ }^{1} \mathrm{H}$ NMR $\left(700 \mathrm{MHz}, \mathrm{CDCl}_{3}\right): \delta=8.21(\mathrm{~d}, J=15.5 \mathrm{~Hz}, 1 \mathrm{H}), 8.10(\mathrm{~d}, J=$ $16.0 \mathrm{~Hz}, 1 \mathrm{H}), 7.71(\mathrm{~d}, J=7.4 \mathrm{~Hz}, 2 \mathrm{H}), 7.68(\mathrm{~d}, J=7.4 \mathrm{~Hz}, 2 \mathrm{H}), 7.63-$ 7.61 (m, 2 H), 7.54-7.51 (m, 2 H), 7.50-7.47 (m, 1 H), 7.46-7.32 (m, 8 $\mathrm{H}), 2.42$ (s, $3 \mathrm{H})$. 
${ }^{13} \mathrm{C}$ NMR $\left(176 \mathrm{MHz}, \mathrm{CDCl}_{3}\right.$ ): $\delta=166.8,161.5,161.1,139.2,137.9$, 136.9, 136.6, 136.5, 129.3, 129.2, 129.0, 128.9, 128.8, 128.8, 128.5, $128.3,127.9,127.7,122.9,122.3,15.2$

HRMS (ESI+): $m / z[\mathrm{M}+\mathrm{Na}]^{+}$calcd for $\mathrm{C}_{27} \mathrm{H}_{22} \mathrm{~N}_{2} \mathrm{Na}$ : 397.1675; found: 397.1679.

\section{Dimethyl 4,4'-(5-Methyl-6-phenylpyrimidine-2,4-diyl)dibenzoate (20)}

White solid, $21 \%$ yield; $\mathrm{mp} 188-190{ }^{\circ} \mathrm{C}$.

IR (neat): 3084, 3059, 3027, 2949, 2843, 1719, 1527, 1434, 1388, $1274,1191,1112,1098,1004,859,761 \mathrm{~cm}^{-1}$.

${ }^{1} \mathrm{H}$ NMR $\left(400 \mathrm{MHz}, \mathrm{CDCl}_{3}\right): \delta=8.65-8.59(\mathrm{~m}, 2 \mathrm{H}), 8.24-8.19(\mathrm{~m}, 2 \mathrm{H})$, 8.16-8.11 (m, 2 H), 7.84-7.79 ( $\mathrm{m}, 2 \mathrm{H}), 7.77-7.71$ ( $\mathrm{m}, 2 \mathrm{H}), 7.57-7.50$ $(\mathrm{m}, 3 \mathrm{H}), 3.98(\mathrm{~s}, 3 \mathrm{H}), 3.95(\mathrm{~s}, 3 \mathrm{H}), 2.39(\mathrm{~s}, 3 \mathrm{H})$.

${ }^{13} \mathrm{C}$ NMR $\left(101 \mathrm{MHz}, \mathrm{CDCl}_{3}\right): \delta=167.6,167.1,166.8,166.3,160.8$, $143.4,141.9,138.9,131.7,130.9,129.8,129.8,129.5,129.4,128.6$, $128.3,124.2,52.5,52.3,17.8$.

HRMS (ESI+): $m / z$ [M + Na] $]^{+}$calcd for $\mathrm{C}_{27} \mathrm{H}_{22} \mathrm{~N}_{2} \mathrm{NaO}_{4}: 461.1472$; found: 461.1466 .

\section{Synthesis of Pyridines 3a and 3b}

All reactions were run on a $0.2 \mathrm{mmol}$ scale, using the same general procedure as for the synthesis of pyrimidines $\mathbf{2 a - 0 .}$

\section{4-(4-Methoxyphenyl)-2-phenyl-6,7-dihydro-5H-cyclopenta[b]pyr-} idine (3a)

Light-yellow solid, $45 \%$ yield.

IR (neat): 3060, 3036, 2952, 2836, 1608, 1590, 1556, 1513, 1458, $1440,1371,1250,1177,1132 \mathrm{~cm}^{-1}$.

${ }^{1} \mathrm{H}$ NMR $\left(600 \mathrm{MHz}, \mathrm{CDCl}_{3}\right): \delta=8.00-7.97(\mathrm{~m}, 2 \mathrm{H}), 7.51-7.44(\mathrm{~m}, 5 \mathrm{H})$, 7.42-7.34 (m, $1 \mathrm{H}), 7.04-6.99(\mathrm{~m}, 2 \mathrm{H}), 3.88(\mathrm{~s}, 3 \mathrm{H}), 3.15(\mathrm{t}, J=7.6 \mathrm{~Hz}$, $2 \mathrm{H}), 3.07(\mathrm{t}, J=7.3 \mathrm{~Hz}, 2 \mathrm{H}), 2.16(\mathrm{p}, J=7.5 \mathrm{~Hz}, 2 \mathrm{H})$.

${ }^{13} \mathrm{C}$ NMR $\left(151 \mathrm{MHz}, \mathrm{CDCl}_{3}\right): \delta=166.8,159.9,156.6,145.6,140.2$, 133.0, 131.5, 129.6, 128.8, 128.5, 127.1, 118.0, 114.2, 55.5, 35.0, 31.0, 23.7.

HRMS (ESI+): $m / z[M+H]^{+}$calcd for $\mathrm{C}_{21} \mathrm{H}_{20} \mathrm{NO}$ : 302.1539; found: 302.1542 .

\section{4-Methyl-2-phenyl-6,7-dihydro-5H-cyclopenta[b]pyridine (3b)}

Light-yellow solid, 63\% yield.

IR (neat): 3057, 2946, 2841, 1595, 1577, 1457, 1437, 1424, 1377, $1228,1076,1028,864 \mathrm{~cm}^{-1}$.

${ }^{1} \mathrm{H}$ NMR $\left(600 \mathrm{MHz}, \mathrm{CDCl}_{3}\right): \delta=7.94-7.92(\mathrm{~m}, 2 \mathrm{H}), 7.46-7.42(\mathrm{~m}, 2 \mathrm{H})$, 7.38-7.34 (m, $1 \mathrm{H}), 7.29(\mathrm{~s}, 1 \mathrm{H}), 3.09(\mathrm{t}, J=7.7 \mathrm{~Hz}, 2 \mathrm{H}), 2.90(\mathrm{t}, J=7.4$ $\mathrm{Hz}, 2 \mathrm{H}), 2.31$ (s, $3 \mathrm{H}), 2.20-2.11(\mathrm{~m}, 2 \mathrm{H})$.

${ }^{13} \mathrm{C}$ NMR $\left(151 \mathrm{MHz}, \mathrm{CDCl}_{3}\right): \delta=165.4,156.3,143.4,140.3,134.9$, $128.7,128.4,127.1,119.6,34.7,29.1,22.7,19.2$.

HRMS (ESI+): $m / z[M+H]^{+}$calcd for $\mathrm{C}_{15} \mathrm{H}_{16} \mathrm{~N}$ : 210.1277; found: 210.1278 .

\section{Funding Information}

Funding by the European Research Council (ERC CoG VINCAT 682002) and the FWF (Project 30226) is acknowledged.

\section{Acknowledgment}

The continued support of the University of Vienna to our research programs is acknowledged.

\section{Supporting Information}

Supporting information for this article is available online at https://doi.org/10.1055/s-0037-1610411.

\section{References}

(1) Joule, J. A.; Mills, K. Heterocyclic Chemistry; Wiley: Hoboken, NJ, 2009, 5th ed.

(2) (a) Mohana Roopan, S.; Sompalle, R. Synth. Commun. 2016, 46, 645. (b) Walker, S. R.; Carter, E. J.; Huff, B. C.; Morris, J. C. Chem. Rev. 2009, 109, 3080. (c) Gompper, R.; Mair, H.-J.; Polborn, K. Synthesis 1997, 696. (d) Itami, K.; Yamazaki, D.; Yoshida, J.J. Am. Chem. Soc. 2004, 126, 15396. (e) Lagoja, I. M. Chem. Biodiversity 2005, 2, 1. (f) Panneer Selvam, T.; Richa James, C.; Vijaysarathy Dniandev, P.; Karyn Valzita, S. Res. Pharm. 2012, 2, 1.

(3) For a review, see: (a) Gore, R. P.; Rajput, A. P. Drug Invent. Today 2013, 5, 148. For selected examples, see: (b) Wang, R.; Guan, W.; Han, Z.-B.; Liang, F.; Suga, T.; Bi, X.; Nishide, H. Org. Lett. 2017, 19, 2358. (c) Fandrick, D. R.; Reinhardt, D.; Desrosiers, J.-N.; Sanyal, S.; Fandrick, K. R.; Ma, S.; Grinberg, N.; Lee, H.; Song, J. J.; Senanayake, C. H. Org. Lett. 2014, 16, 2834. (d) Chu, X.-Q.; Cao, W.-B.; Xu, X.-P.; Ji, S.-J.J. Org. Chem. 2017, 82, 1145. (e) Deibl, N.; Kempe, R. Angew. Chem. Int. Ed. 2017, 56, 1663. (f) Stonehouse, J.; Chekmarev, D.; Ivanova, N.; Lang, S.; Pairaudeau, G.; Smith, N.; Stocks, M.; Sviridov, S.; Utkina, L. Synlett 2008, 100. (g) Reddy, L. S.; Reddy, T. R.; Reddy, N. C. G.; Mohan, R. B.; Lingappa, Y. Synthesis 2013, 45, 75. (h) Guo, W.; Li, C.; Liao, J.; Ji, F.; Liu, D.; Wu, W.; Jiang, H.J. Org. Chem. 2016, 81, 5538. (i) Guo, W.; Liao, J.; Liu, D.; Li, J.; Ji, F.; Wu, W.; Jiang, H. Angew. Chem. Int. Ed. 2017, 56, 1289.

(4) (a) Fuji, M.; Obora, Y. Org. Lett. 2017, 19, 5569. (b) Liu, D.; Nie, Q.; Cai, M. Tetrahedron 2018, 74, 3020. (c) Satoh, Y.; Yasuda, K.; Obora, Y. Organometallics 2012, 31, 5235. (d) Yang, L.; Hua, R. Chem. Lett. 2013, 42, 769. (e) You, X.; Yu, S.; Liu, Y. Organometallics 2013, 32, 5273.

(5) Xie, L.-G.; Niyomchon, S.; Mota, A. J.; González, L.; Maulide, N. Nat. Commun. 2016, 7, 10914.

(6) (a) Ahmad, O. K.; Hill, M. D.; Movassaghi, M. J. Org. Chem. 2009, 74, 8460. (b) Movassaghi, M.; Hill, M. D. J. Am. Chem. Soc. 2006, 128, 14254. (c) Movassaghi, M.; Hill, M. D. Nat. Protoc. 2007, 2, 2018.

(7) (a) Falmagne, J.-B.; Escudero, J.; Taleb-Sahraoui, S.; Ghosez, L. Angew. Chem., Int. Ed. Engl. 1981, 20, 879. (b) Charette, A. B.; Grenon, M. Can. J. Chem. 2001, 79, 1694. (c) Kaiser, D.; Maulide, N. J. Org. Chem. 2016, 81, 4421. (d) Ruider, S.; Maulide, N. Angew. Chem. Int. Ed. 2015, 54, 13856.

(8) For our recent work on amide activation with triflic anhydride, see: (a) Tona, V.; de la Torre, A.; Padmanaban, M.; Ruider, S.; González, L.; Maulide, N. J. Am. Chem. Soc. 2016, 138, 8348. (b) Tona, V.; Maryasin, B.; de la Torre, A.; Sprachmann, J.; González, L.; Maulide, N. Org. Lett. 2017, 19, 2662. (c) de la Torre, A.; Kaiser, D.; Maulide, N. J. Am. Chem. Soc. 2017, 139, 6578. (d) Shaaban, S.; Tona, V.; Peng, B.; Maulide, N. Angew. Chem. Int. Ed. 2017, 56, 10938. (e) Di Mauro, G.; Maryasin, B.; 
Kaiser, D.; Shaaban, S.; González, L.; Maulide, N. Org. Lett. 2017, 19, 3815. (f) Kaiser, D.; Teskey, C. J.; Adler, P.; Maulide, N. J. Am. Chem. Soc. 2017, 139, 16040.

(9) (a) Huang, P.-Q.; Huang, Y.-H.; Geng, H.; Ye, J.-L. Sci. Rep. 2016, 6, 28801. (b) Medley, J. W.; Movassaghi, M. J. Org. Chem. 2009, 74, 1341.

(10) It is likely that the 2 equivalents of cyclopentyl carbocation eliminated ultimately lead to cyclopentene by proton loss (E1). Given the volatility of cyclopentene, it was not possible to detect its presence in the reaction mixture.

(11) (a) Thummel, R. P. In The Chemistry of Heterocyclic Compounds: A Series of Monographs; Newkome, G. R., Ed.; John Wiley \& Sons, Inc: Hoboken, NJ, 2008, Part 5, Vol. 14 253-445. (b) van der Plas, H. C. ARKIVOC 2008, (iii), 127.

(12) (a) Friedlaender, P. Ber. Dtsch. Chem. Ges. 1882, 15, 2572. (b) Marco-Contelles, J.; Pérez-Mayoral, E.; Samadi, A.; Carreiras, M. do. C.; Soriano, E. Chem. Rev. 2009, 109, 2652.

(13) Dihydropyridine $\mathbf{4}$ has been detected by HRMS in several reactions but was never isolated.
(14) Charman, H. B.; Rowe, J. M. J. Chem. Soc. D 1971, 476.

(15) Apsunde, T.; Trudell, M. Synthesis 2014, 46, 230.

(16) Kokare, N.; Nagawade, R.; Rane, V.; Shinde, D. Synthesis 2007, 766.

(17) Fang, C.; Qian, W.; Bao, W. Synlett 2008, 2529.

(18) Jeffrey, J. L.; Bartlett, E. S.; Sarpong, R. Angew. Chem. Int. Ed. 2013, 52, 2194.

(19) Qu, G.-R.; Song, Y.-W.; Niu, H.-Y.; Guo, H.-M.; Fossey, J. S. RSC Adv. 2012, 2, 6161.

(20) Nordeman, P.; Odell, L. R.; Larhed, M. J. Org. Chem. 2012, 77, 11393.

(21) Zhou, L.; Lu, W. Org. Lett. 2014, 16, 508.

(22) Huang, H.; Morgan, C. M.; Asolkar, R. N.; Koivunen, M. E.; Marrone, P. G. J. Agric. Food Chem. 2010, 58, 9994.

(23) Fuji, M.; Obora, Y. Org. Lett. 2017, 19, 5569.

(24) Pourzal, A.-A. Synthesis 1983, 717.

(25) Liu, J.; Pan, L.; Peng, Q.; Qin, A. Molecules 2017, 22, 16791. 